\title{
The Role of Women in the Sustainability of the Wine Industry: Two Case Studies in Italy
}

\author{
Graziella Benedetto and Gian Luigi Corinto
}

\begin{abstract}
The chapter aims at analyzing whether female entrepreneurs have some distinctive capacities than men in managing business within the Italian wine industry and if these skills are useful for the sustainability of their farms and the whole sector. After the sketch of the women situation in the Italian agriculture and in the wine sector, we have analyzed two case studies located in two wine regions, Tuscany and Sardinia, by having meetings and interviewing two wine women. The two regions are quite different for the general condition of winemaking and for the internationally perceived image. Furthermore, the two informants have different family histories and manage different dimensioned farms. Our findings are that these two female entrepreneurs, even starting from different general conditions, have been able to use their own leading capabilities in the improvement of business and in collective regional and national initiative of wine promotion. Basing economic decisions on formal and/or contextual training, they have introduced innovations in farming, winemaking, and marketing in a specific way. We can say they have been someway slower, less hasty, and even more effective than men in involving collaborators with a charismatic heading and attracting other entrepreneurs in doing business. The role of women in farming has been too long underrated by society and the policymakers, who, on the contrary, should provide more specific attentions to the female capacity to foster the sustainability of their own farms and the wine Italian industry.
\end{abstract}

\footnotetext{
G. Benedetto $(\bowtie)$

Department of Science for Nature and Environmental Resources, University of Sassari,

Sassari, Italy

e-mail: gbenedet@uniss.it

G.L. Corinto

Department of Education, Cultural Heritage and Tourism, University of Macerata, Macerata, Italy

e-mail: gianluigi.corinto@unimc.it
} 


\section{Introduction}

Even recent researches (Piacentini 2013) show persisting gender differences in labor market all over the world. Entrepreneurship is the dimension where gender differences are the most marked, and still today, business women are much less than men, and their ventures are usually small and operate with little capital. Italy is not an exception and not the Italian agriculture.

For decades the increasing presence of women in the Italian agriculture has been interpreted as a signal of loss of competitiveness since the term "feminization" has been often used in combination with the "senilization" (aging) of farmers indicating the weakening of entrepreneurial capabilities within the farmers (Bandini 1967). The traditionally underrated role of women in farming has been determinedamong other causes - by the hereditary system of land property that privileged the masculine line and even more by the social role of raising children and preparing and serving food, usually performed by housewives (Mennell et al.1992; Couniham 2004). The large diffused mezzadria, i.e., the sharecropping land tenure, underlined the dependent role of rural housewives in the household economy, with a clear division between male and female duties, and otherwise it was also the basis for extensive socioeconomic mutations (Ciuffoletti and Contini 1994). In Central Italy, farming systems and the landscapes are strictly intertwined, and both refer to a particular organization of the agricultural habitat within, with functional relations between housing and farming, settlement and the countryside, and houses and cultivated fields being detectable (Polidori 2013). The specific objective of this kind of land tenure was to have enough foodstuffs both for the farming family and the landowner and his family. Indeed, the middle-upper class of landlords aimed at living "off one's own means," and thus, the overall land tenure was oriented to self-consumption (Jones 1980). The role of women was clearly subordinated, both in working class and in landowners.

The traditional role of rural women faced a striking change in the half of the twentieth century, when masses of rural people abandoned farming employment and rural residences (De D'Attorre and Bernardi 1994) to live in cities and work in nonagricultural industries following the general social mutation of the Italians (Corinto 2014). The agricultural and rural exodus interested both men and women, regarding younger and more skilled and willing to risk people, being agriculture clearly viewed as a poor sector for weaker entrepreneurs and workers, i.e., women and the elders (Bartoli et al.2011).

According to Barberis (1963), the feminization of agriculture, already started in the 1950s and 1960s, is to be considered as the factual emersion of the female selfemployed farming, a phenomenon previously near invisible. At the end of the past century, in 1997, the European Commission (Commissione Europea 2002) showed the highest percent of female farm managers was localized in the Southern Italy (Abruzzo, Molise, Campania, Basilicata, all ranking between 28 and the $41 \%$ ). In particular, in Sardinia, the female emancipation has a long history, due to the centuries-old absence of male shepherds (the husbands) from the family house 
and the subsequent establishment, as a matter of fact, of a matriarchy and a female mayor propensity to training studies (Barberis 2009).

During the 1990s, feminization of agriculture "became a female sound presence in the guide and proper managing of the farm with several innovative characteristics" (Tazza 2010, p. 119). Today this "feminizing" trend continues, and women are more numerous than in the past, both among workers and farm owners and managers. Recently, a study performed by the Italian Minister of Labor enlightened some general traits of women entrepreneurs: "it emerges a model of a female entrepreneur/manager that mainly privileges a cooperative network system that includes business, community and family, fostered by the relational skills typical of women. Female entrepreneurial styles are characterized by flexible solutions in relation to the different phases of the woman's life and the difficulty of the diverse works and private/family timing of tasks, especially when women have kids. Otherwise, there are still copious facts that hinder the women/labor-market relationship, regarding women both entrepreneurs and workers" (Unioncamere 2011, p. 13).

An important point to underline is the generally stronger capacity of the female enterprises to face the current economic crisis. "At the national level, the increasing number of female enterprises [...] during the crisis has more than balanced the decreasing of the male ones" (Unioncamere 2011, p. 13).

Women have different skills than men in terms of perception/sixth sense, or in organizational jargon "emotional intelligence," and in managerial jargon "multitasking" abilities due to the daily necessity to face simultaneous different responsibilities (Goleman 2001).

According to Rea (2009), a "women diversity" actually exists, stated in managerial studies and social psychology (Piccardo and Baiunco 2007; Piccardo et al.2008) that have put in light the female diversity in comparison to the male leadership. The female leadership shows "communal" features, such as cooperativeness, generosity, and empathy. The male leadership shows more "agent" features, such as self-confidence, assertiveness, and control.

A recent study (Rea 2009) realized that the distinction between "transactional and transformational leadership" (Burns 1978; Bass 1985) fits well for analyzing the female entrepreneurship. Indeed, women show a "transformational leadership" oriented to the commitment and creativity of collaborators, while men more frequently act as "transactional leaders," willing to correct/reward/punish collaborators in relation to the obtained goals (Rea 2009). The transformational leadership could be the expression of a "soft-power" (Nye 2004), while men, performing a "hard-power," actually use a top-down management. Moreover, Arlenghi (2014) reported the soft aptitudes of women are most wanted by modern companies, organized in reticular and less hierarchical schemes.

Then, our case studies aim at analyzing the role of women managers in the Italian winemaking sector, focusing in their innovation capabilities and the effects on sustainability as stated even in the Europe 2020 strategy and in particular in the Italian wine industry. 
In Italy, the Italian Association Le Donne del Vino (The Women of Wine) was born in 1988 aiming at gathering all women committed to the realm of wine. They are female winemakers, marketers, managers of wineshops, sommeliers, restaurant owners, journalists, academicians, and researchers on the wine sector. From the origin up to today, the number of women of wine has increased from 8 to 800 .

Five years ago, a dedicated study on the female perception of wine consuming behavior modifications has been performed (Rea 2009), just using the "universe" of the Women of Wine association. This study enlightened the female tendency to use the marketing leverages of communications and events organization, within the singular farm and involving the territory (Rea 2009).

We have adopted a different research perspective, more focused on the nexus between female entrepreneurship, innovation, and sustainability.

Therefore, the chapter reports results of two case studies, performed by deep face-to-face interviews to female entrepreneurs acting in the Italian wine industry. We describe and interpret the ongoing role of women in the wine sector, giving some enlightenments on economic and social reasons of the importance of women as wine entrepreneurs.

The rest of the chapter is organized as follows. Section 2 reports the overall situation of farming, winemaking, and rural tourism, even sketching the presence and role of women and female entrepreneurs. Section 3 reports background literature and research focus, questions, and method. Section 4 reports the narrative of the two case studies, the Fattoria del Colle and Tenute Olbios, respectively located in Tuscany and Sardinia, as resulted from the interviews. Section 5 is dedicated to discuss our findings and Sect. 6 gives the conclusions.

\section{Background: The Overall Situation of Farming, Winemaking, and Rural Tourism in Italy}

Between 2000 and 2010, years of the 5th and 6th Agricultural Italian Census (ISTAT 2002, 2010), the owned farming land tenure continued to prevail over the waged-labor-based one (Table 1), but farms have reduced by 533,000 units $(-24.7 \%)$. In particular, female holdings decreased by 107,000 units $(-16.7 \%)$, while male ones showed a stronger reducing equal to 426,000 units $(-28.1 \%)$, almost in all the geographical zones of Italy. This data proves the general tendency of women's resistance against the crisis even in agriculture, so that the percentage of women in farming increased from $29.8 \%$ to $33 \%$ (Table 2) and from 28.0 to 33.2 in tourist farms (Table 3).

The latest Agricultural Census (ISTAT 2010) showed in 2010 that there were $1,630,420$ agricultural holdings. The total agricultural area (TAA) was $17,277,023$ ha and the utilized agricultural area (UAA) was equal to $12,885,186$ ha. Agricultural holdings are mainly managed by individuals or 
Table 1 Italy. Land tenure in 2000 and 2010

\begin{tabular}{l|c|c}
\hline Land tenure & 2000 & 2010 \\
\hline Owned farming & 95.4 & 95.0 \\
\hline Waged labor based & 4.5 & 4.3 \\
\hline Others & 0.1 & 0.7 \\
\hline
\end{tabular}

Sources: ISTAT $(2002,2010)$

Table 2 Italy. Farm managers per gender and variations in 2000 and 2010

\begin{tabular}{l|l|l|l|l|l|l}
\hline & \multicolumn{6}{l}{ Farm managers } \\
\cline { 2 - 7 } & Men & Women & \multicolumn{2}{l}{ Total } \\
\hline Year & $n$ & $\%$ & $n$ & $\%$ & $n$ & $\%$ \\
\hline 2000 & $1,512,169$ & 70.20 & 641,555 & 29.80 & $2,153,724$ & 100 \\
\hline 2010 & $1,086,619$ & 67.00 & 534,265 & 33.00 & $1,620,884$ & 100 \\
\hline Variations (\%) & -28.14 & & -16.72 & & -24.74 & \\
\hline
\end{tabular}

Sources: ISTAT $(2002,2010)$

Table 3 Tourist farm managers per gender and variations 2000-2010

\begin{tabular}{|c|c|c|c|c|c|c|}
\hline \multirow[b]{3}{*}{ Year } & \multicolumn{6}{|c|}{ Farm managers } \\
\hline & \multicolumn{2}{|l|}{ Men } & \multicolumn{2}{|c|}{ Women } & \multicolumn{2}{|l|}{ Total } \\
\hline & $n$ & $\%$ & $n$ & $\%$ & $n$ & $\%$ \\
\hline 2000 & 8,924 & 72.00 & 3,472 & 28.00 & 12,396 & 100 \\
\hline 2010 & 12,902 & 66.8 & 6,402 & 33.2 & 19,304 & 100 \\
\hline Variations $(\%)$ & \multicolumn{2}{|l|}{44.58} & \multicolumn{2}{|l|}{84.39} & \multicolumn{2}{|l|}{55.73} \\
\hline
\end{tabular}

Sources: ISTAT 2002, 2010

families (96\%), and the manager is the landowner himself/herself (95\%) or runs family lands $(65.5 \%)$.

Among the tree crops, viticulture is practiced by 383,645 companies, $23.5 \%$ of the total, and covers 632,000 ha, equivalent to the $4.9 \%$ of the UAA. The average size of vines is 1.6 ha, increasing by 0.7 ha in comparison to 2005 .

The Italian wine sector is in very good health, as stated by Mediobanca (2014). For this research institute, the turnover in 2013 increased by $4.8 \%$, due more to export $(+7.7 \%)$ than the inner market reaching $24.1 \%$ over the 2008 level. The level of employment has increased between 2008 and 2012 in countertendency to the downsizing of the beverage sector $(-5.2 \%)$ and the manufacturing industry as a whole $(-6 \%)$. In 2013, Italy is still the main wine producers in the world with a total of 44.9 million hectoliters, preceding France (44.1 million) and Spain (40.0 million). The total value is estimated to be 9.1 billion euro.

In 2013, the top three Italian companies were Cantine Riunite-GIV (534 million of turnover), the Caviro Group (327 million), and the wine division of Campari (228 million). We must underline that at the fourth position, there is the Antinori company (with 166 million euro) that has three women at the top management and strategic marketing office. 
Some details about agricultural tourism and the quality productions are given. In the abovementioned decreasing number of agricultural holdings, agricultural farms showed a clear opposite tendency. Between 2003 and 2012, tourist farms increased from 13 to 20.5 thousand units $(+57.3 \%)$, and female-conducted ones increased from 4.3 to 7.3 thousand $(+67.9 \%)$ while male-conducted ones from 8.7 to 13.2 thousand $(+51.9 \%)$. In tourist farm, owning the rate of women increased from 33.2 to $35.5 \%$.

Data show that farm tourism is clearly increasing and the female percentage contribution is quite higher than the masculine one (Adua 2014).

In conducting farms of AOC and PGI chains, the female managers are in average less young than men and have less UAA but, on the opposite, work more in the organic farming, have a higher degree of instruction, and live more frequently in the hilly countryside (Adua 2014).

\section{Background Literature and Research Focus, Questions, and Method}

According to recent scholars' statements, the past vision of "feminization" as a negative attribute "is inadequate to understand the today variation of farm tenure and managing in Italy" (Sabbatini 2006, our translation). Today, "even multifunctionality and generational turnover in agriculture are fostered by women" (Sabbatini 2006, p. 20, our translation).

Rosenberg (1963) defined technological innovation as a major ingredient of long-term economic growth, characterized by a high degree of uncertainty. In this sense, innovations introduced by female rural entrepreneurs (in particular in winemaking and wine tourism) deal with technological and market uncertainty and have many ingredients of sustainability having surely a long-term vision.

In this line, the role of social capital and human capital (according to Becker 1962, 1975; Schultz 1960, 1964) and their reciprocal interrelations matter and have been tested in the Italian rural development (Benedetto 2011).

The updating of agriculture by the modification of the different forms of human, physical, and organizational capital (as stated mainly by Shultz) is an important research topic and a means for the sustainability even for wine farms.

Thus, our research focus is on the role of female entrepreneurs in using their specific capabilities and skills for the sustainability of their farms and the territories where they live and make business. Our research questions are as follows:

- Do women have a specific attitude in making business in the Italian wine industry?

- Are they able to perform feasible farming and marketing decisions in order to design a sustainable development of their business?

- Can they reconcile their family responsibilities to perform a charismatic leadership? 
In order to find data useful to answer the research questions, we made two case studies following the qualitative method, gathering informations indirectly from press and the Web and directly from face-to-face interviews (Tremblay 1955; Kvale 1996; Marshall 1996; Bradburn et al. 2004) to women entrepreneurs engaged in the managing of vineyards and wine farms.

We have chosen to perform the interviews in two quite dissimilar Italian regions: Tuscany and Sardinia, which do actually represent very far wine poles in the Italian panorama. Thus, the comparison will help us in verifying the female behavior and the women perception of their own managerial "diversity" in utmost different socioeconomic environments.

\section{Case Studies}

The two case studies have been carried out following the abovementioned literature and aiming at focusing:

- A general picture of the wine farm and the history of the female managing

- Main issues of the winemaking and selling with a specific attention to sustainable goals

- The actual female contribution to the "organizational form" and innovation of the farm

- The interviewee's perception about the distinctive capabilities of a female managing

\subsection{Fattoria del Colle, Interview to Mrs. Donatella Cinelli Colombini}

The Fattoria del Colle farm is located in the municipality of Montalcino, province of Siena, and has a very long story and is linked to a famous and renowned red wine, the Brunello di Montalcino.

The first testimonies of the farm house have roots in the twelfth century. Over time, the whole real estate faced several changes and today has 336 ha lying on the hills in front of the village, where wines such as Brunello, Chianti Classico, and Nobile di Montepulciano have their historical growing place.

In 1998, Mrs. Donatella Cinelli Colombini inherited the farm house Fattoria del Colle, where she today manages 160 ha of cereals, 6 ha of olive tree yards, and 22 of vineyards, cultivating varieties of Sangiovese, Merlot, Traminer, and Foglia Tonda, which is an old vine, neglected for centuries. The Foglia Tonda variety remained in obscurity for a long time, but was rediscovered in the 1870 s by Giuseppe Conti de Rovasenda, one of Italy's famous early ampelographers. It was finally admitted to Italy's Registro Nazionale delle Varietà di Vite (national register of wine grape 
varieties) in May 1970, still being neglected. Today, one of Foglia Tonda's strongest advocates as a blending ingredient is the Donatella Cinelli Colombini winery, whose Sangiovese-based Cenerentola wine (Orcia DOC) includes a greater portion of Foglia Tonda with each vintage that passes.

Mrs. Donatella Cinelli Colombini was born in 1953 into a family of Brunello di Montalcino's producers. Today, she manages two wineries, the Fattoria del Colle and the Casato Prime Donne, in the municipality of Trequanda and Montalcino, respectively, both in the province of Siena.

This real estate pertained to the ancestors of Mrs. Donatella yet in 1592, and in more recent year, it has been owned by her grandmother and then by her mother Francesca and in the future will be inherited by her daughter Mrs. Violante Gardini, in an evident female line.

In 1993, Donatella Cinelli Colombini, daughter of Francesca, the "Lady of Brunello," invented the first edition of Cantine aperte (Open Cellars) after the research proposed to Magda Antonioli Corigliano (1999) and the publication of the first identikit of wine tourists. Following this initiative, the Wine Tourism Movement took place in an increasing successful tendency over time. This specific feminine innovation was continued by Donatella Cinelli Colombini who started in 1998, the first Italian cellar with an entire female staff, the Casato Prime Donne, in Montalcino. In 2000, for the Christian Jubilee, Women of Wine presented "2,000 wines from Women of Wine," and the same Woman of Wine in 2001 organized the first edition of Calici di Stelle (Calices of Stars) during the first decade of August.

"I had the duty from VIDE-Italian Excellence Vine-growers-to promote public relations, almost with no budget. I adopted a questionnaire for visitors of VIDE farms. I realized it was the very first time anyone entered such a survey. So I proposed the new event Cantine aperte (Open cellars). In 1998 I was searching for an enologist. All the male enologist graduated in Siena were employed by main producers, and there were many unemployed women. That's matched to my goal to have an entire female staff" (Donatella Cinelli Colombini).

The success of the movement and the associationism initiative has been clear, also due to the increasing interest about women's behavior in wine consuming. Today, the associated women are nearly up to 700. Young and trained women (with an academic degree in agriculture and enology) as associated members are increasing, and many women enter the world of wine not due to a family heritage but as a choice of life.

Within the family, Mrs. Donatella is the farm manager and is directly responsible for the communication. Her daughter, Mrs. Violante, is the executive sales manager for the wine.

\footnotetext{
"My Grandfather, Giovanni Colombini, was the person that influenced me more. He taught me the value of typical products, the importance to develop the entire supply chain up to the final consumer. Form pigs to the selling of cold cuts, from sheep to cheese, from vineyards to the exportation of our bottles with our brand. He was the first who opened the cellar to public visits, even starting a farm restaurant salami, still in the 80s" (Donatella Cinelli Colombini).
} 
The total wine production of the winery is sold abroad for the $60 \%$, while the $24 \%$ in Italy and the $16 \%$ at the cellar. All the vineyards are grown organically even if not certified, and the farm benefits from solar panels for producing about a quarter of the total energy needs.

The entrepreneurial activity of Mrs. Donatella has also evident public facets, at the national level in the life of the Movimento delle Donne del Vino and at the local level being the President of the AOC Orcia Consortium, fostering the project "Orcia, the most beautiful wine in the world." This initiative aims at transforming the million visitors of the area in the "Orcia wines" estimators and consumers.

In view of this goal, all the wineries will improve the linkages between landscaping and wine growing, building belvedere (beautiful panoramas), and hosting trekkers. The communication plan will be made by setting advertising totems in the car parkings, distributing a 100,000 of leaflets and 30,000 maps, and making a pushing Internet and social media marketing.

When Mrs. Donatella assumed the executive direction of the Fattoria del Colle, in 1998, within the village of Trequanda, there were no wineries, while today there are five. The publishing of a cooking recipes book as well as other continual initiatives of press office and public relations made the place more known and visible worldwide, inducing a tourist flux, encouraging other people to make investments and businesses.

In the area of Montalcino, the innovating action is less incisive than in that of the Orcia Valley, because the willing to innovate is less strong, probably due to the well-developed brand of the territory in comparison to the last one. Nevertheless, the Benvenuto Brunello (Welcome Brunello) event, which takes place every year in February, presenting to the press the new wines on the market since the beginning of the new year, has been welcomed by everyone.

In concluding the narrative of Mrs. Donatella Cinelli Colombini, a peculiar finding must be underscored about the idea of a "specific female organizational form" of the enterprise, as perceived by her:

\footnotetext{
"The 'female' managing is little centralized and very flexible. There is a very high propensity to reconcile personal needs with the business. Every decision and initiative is the result of a team effort and a collective 'laboratory of ideas.' We invest in the training and external partnerships that can bring innovation."
}

\subsection{Tenute Olbios, Interview to Mrs. Daniela Pinna}

The Tenute Olbios (from the root of a Greek word meaning "felix, rich, and fertile land") is a young farm located in the municipality of Olbia, in the province of Sassari, within the zone of Gallura, the very birthplace and sole productive area of the CGDO Vermentino. The locality is named Venafiorita (due to the presence of good water) in the countryside of Olbia, just in front of the northern coast of Sardinia, yet being very close to the city of Sassari, in a particularly favorable location. 
The farm has 60 ha of vineyards, managed by Mrs. Daniela, who was laureate in Agricultural Sciences at the University of Sassari. She self-provided a specialization in vine growing and wine processing, following a personal aptitude, and choosing selected specialized courses and a specific final dissertation, because the university had not yet established an autonomous Degree in Food and Wine technologies. Her specific goal was to manage the owned farm having competencies in winemaking and marketing.

The mother figure was "for better or for worse," very fundamental to the choices of Mrs. Daniela. On the one hand, her mother has been always attached to the land property, even when left alone, a widow with three children, always rejecting any favorable buying offer for the farm. "In Sardinia hardly someone sells the land" (Daniela Pinna).

On the other hand, the mother showed a strong opposition to the training of Daniela in agriculture and winemaking, emphasizing all the difficulties she could meet as a female entrepreneur.

In 2003, Mrs. Daniela became the farm manager and built together with her husband the Tenute Olbios wineries, with very few funds. The business increased, still slowly, as happens "when you have small monetary funds. This is the typical case of many historical wineries, which have a slow evolution over time, not having a sudden success, yet avoiding an equally sudden decline" (Daniela Pinna).

First, she bought secondhand machineries for pressing and refrigerating phases, performing different tests of wine production mainly with the Vermentino di Gallura grape, in order to have the first production of wine. The company profit is always reinvested in the farm.

An old industrial stazzo (a traditional one-story rural building of Gallura), already within the center of the farm and with high ceiling, has been refurbished for the wine vats settlement.

The development project was quality and environmentally oriented and the farming still follows the organic principles.

Mrs. Daniela retained all her mother's employees, because they were the memory of the farm, and allowed her to know everything that has been made within the rows of the vines, even if she perceived difficulties in their acceptance of innovative techniques. She used profitably her scientific training, albeit with prudence and diplomacy, introducing gradually all technical innovation she decided.

In 2006, Daniela introduced the bottling plant and started production with a single selection, the Vermentino di Sardegna DOC Lupus in Fabula, dedicated to her mother.

In 2007, she started to produce red wine, after replanting over time 10 ha of vineyards, choosing native red grapes and updating the winemaking techniques. After doing tests for red and rose wines, the Nessuno (Nobody), a full-bodied wine with a very intense flavor, was born. The brand name was derived from the name of Ulysses, as recent studies stated the Greek hero passed by the Northern Sardinia during his journey.

In 2008, the fourth new selection, a pure Vermentino di Gallura sparkling wine, has been produced by using the champenoise method. Its soft and velvety taste 
reminded her of the silk texture, so Mrs. Daniela thought of the Sardinian Bisso (a natural fiber produced by a Sardinian fan mussel) and chose that brand name for the sparkling wine.

Just during her meetings with Chiara Vigo, the last master of the marine silk, the Bisso, Mrs. Daniela has been hit by the discourse of Chiara that in Sardinia, women have provided the preservation of the female arts, from food recipes to weaving and much more.

Mrs. Daniela has always been very careful to recover the island traditions, usually combining her wines with local typical products in the farm tasting room. Moreover, she has involved many Sardinian artists in designing the wine bottle labels.

Recently, she has introduced new services, such as the possibility to book a dining at the farm, in collaboration with two Sardinian chefs she hosts in the farm kitchens. Then she organized Cooking Classes for teaching bread and pasta making, with the collaboration of a professional who was a University mate of her. The farm participates in the Tourism of Wine Movement and has organized events such as Cantine aperte (Open Cellars) and Cinema in cantina (Movies in the Cellars).

Another crucial element is the abatement of any architectural barriers to allow disabled people to visit throughout the farm.

The Tenute di Olbios sells near all the production only through the HORECA chain and frequently hosts sommeliers who visit the place of wine production, in order to be able to make a specific storytelling to final consumers. Mrs. Daniela, in the role of executive sales manager, had implemented the commercial network with agents, distributors, and importers in Italy and worldwide.

From 2010, Mrs. Daniela Pinna is the President of the CGDO Vermentino di Gallura consortium. In this role, she has contributed to an important law innovation, allowing the past prohibited use of alternative caps than corks and inducing even the modification of the Vermentino production disciplinary.

She has been the second Italian winemaker who used the glass stopper for wine bottles, considering the exclusive capabilities in maintaining the wine safety during oversea transportation and when the wine oxygenation is not necessary, and above all the overuse of preservatives should be prevented.

The next innovation Mrs. Daniela is going to introduce is in wine pricing, whether clients will undertake to turn back the bottles for recycling, in order to improve the mission of sustainability the farm has undertaken since its establishment.

Telling about the female distinctive aptitudes, Mrs. Daniela Pinna declared some clear perceptions. She asserted that women have without a doubt more refined sensibility and a manner able to introduce innovation softly and elegantly. Moreover women are very disposed to disabled persons, the diffusion of the sense of the place, the involvement of staff also during not working activities (lunches after harvest, participation in family celebrations), and concern for workers' families. Women have a greater resourcefulness and determination in making decisions. Her idea of using glass stoppers has been opposed by male entrepreneurs, who were saying, "We are in Sardinia, the homeland of cork," but results have rewarded her innovative idea. 


\section{Discussion}

We have had the possibility of interviewing two female entrepreneurs active in two very different Italian wine regions, Sardinia and Tuscany. Only Mrs. Cinelli Colombini is the member of the Italian Women of Wine movement. They both have inherited the property of real estates and vineyards through a female line, yet in quite different farming and economic dimensions. Mrs. Donatella Cinelli Colombini belongs to a very ancient family of century-old landowners, farmers, and winemakers. Mrs. Daniela Pinna's family is someway "younger" in farming, and even her farm and winery are younger. The first lady didn't encounter the opposition of the family to undertake the farming venture, while the second one has had to deal with her mother's opposition in becoming a farmer and an entrepreneur. Nevertheless, in both cases, the start-up of the female enterprise is to be considered as factually born within the family.

Even the socioeconomic local environments they must face are quite different. They both live in wine regions, but Sardinia certainly suffers major limitations in wine traditions than Tuscany, especially about the national and international reputation of branded wines and terroirs, and even for the same whole image of the region. Nevertheless, they both showed a strong personal orientation to farming and marketing - and in particular to communications and public relations. Mrs. Donatella Cinelli Colombini invented some collective national level events (Open Cellars and Chalices of Stars), then followed by many of the Italian wineries over time, besides the recovery of old vines in winemaking and the continuing attention in improving the control of quality and the entire supply chain of any production, including hospitality. Today, she heads an "all-female staff” in her wineries, being a singular and atypical Italian case.

The Sardinian case study is particularly useful in reflecting the importance of the human capital (a la Schultz) in the performances of the business. Thus, the acquired formal training allowed the accumulation of skills which have been essential for the adoption of technical innovations, including the decision to have a farm wine processing, bottling, and distribution. This is in evident accordance with the research of Barberis (2009) on the evidence of a mayor density of graduated women in Sardinia than in the rest of Italian rural areas.

Mrs. Daniela Pinna even adopted some strong technical innovations such as the use of glass stoppers, showing courageous capacity in a cork-producing region such as Sardinia.

We can, thus, argue that their distinctive capacities in "leadership" and in "making community" led both of them to the apical role of President in CGDO wine consortiums.

We can link innovation capabilities surveyed in the case studies to sustainability. The two female entrepreneurs did "sustainability" in different manners, even though they both have adopted organic farming without requesting an official certification. The "sustainability" they try to achieve is their own farm's longlasting future life, even by means of an evident communication program. In this 
sense, we cannot state that female specificity does actually exist, being evident that any competing firm must struggle against its own capital stock obsolescence (including human skills) if it wants to continue to have profits.

Moreover, a female-specific "resilience" against competition, and then for the sustainability of the firm's long-run life, should be better found in the "soft and elegant" capacity to manage leadership, as stated in general and sectoral literature and confirmed by our informants. The two interviewed women clearly showed soft and solid capacity in involving the internal farm staff and even in managing social relations to improve the role of winemakers, not only women, in the policy of the sector. They focused not only on improving winemaking techniques, or introducing farm hospitality, but even on branding, labeling, wine naming and showing the willingness to care about the necessity of laborers and families, as in the case of the Tenute Olbios.

To be considered as having a broader validity, our findings should be compared in a larger-scale survey, performing and comparing more than two case studies. Nevertheless, the particular choice of the informants, which have different histories but both having been able to reach leading roles in the realm of the Italian wine industry, gives sense to our findings, especially for future deepening on the same topic.

\section{Conclusion}

Our case studies do confirm the modified role and mayor persistence of women than men in the Italian wine industry. Even when starting from a weaker or "marginal" position, in terms of capital endowment and initial minor technical skills, women seems to be perfectly able to improve their training and to introduce innovations in managing their farms in order to ensure a long-run perspective to their businesses. We can say that, at least in the two reported cases, women show some distinctive capabilities. These are retrievable in the capacity to perform leadership in soft and elegant manners, preferring a "transformational" to a "transactional" leadership in order to achieve a charismatic heading.

Both the cases are a testimony on the importance of formal and informal and contextual training in increasing skills and competencies of female entrepreneurs, as either the family or the university can be a source of entrepreneurial capacity improvement.

The multitasking aptitudes of women have been confirmed, as well as their capacity in performing public relations with high-level goals, maintaining the family cohesion as an important and not a secondary target.

Policymakers have not always shown a dedicated attention to the female capacity to make business, and the agricultural sector is even the most effective example. Our study can help policymakers in paying more attention to women's capacity to give a specific form of resilience to the entire sector of agriculture. 
Acknowledgments The authors are indebted to Mrs. Donatella Cinelli Colombini and Mrs. Daniela Pinna for their valuable contribution during the interviews, subtracting time to their activities. Their field experience has been not substitutable for our research aims, and helped us in improving our knowledge on the research topic we wanted to investigate.

Open Access This chapter is distributed under the terms of the Creative Commons Attribution Noncommercial License, which permits any noncommercial use, distribution, and reproduction in any medium, provided the original author(s) and source are credited.

\section{References}

Adua M (2014) Donne e Agricoltura: un connubio di qualità. ISTAT, Roma, 1 Aprile 2014

Antonioli Corigiano M (1999) Strade del Vino ed Enoturismo: distretti turistici e vie di comunicazione. Franco Angeli, Milano

Arlenghi D (2014) L'arte del convincere anziché di costringere. htttp://www.thegraduateschronicle.it/.../soft-power. Accessed 1 Jan 2015

Bandini M (1967) L'agricoltura nel momento attuale. R.E.D.A, Roma

Barberis C (1963) La donna nell'agricoltura italiana. Quaderni di sociologia rurale 2-3:43-55

Barberis C (2009) Ruritalia. La Rivincita delle Campagne. Donzelli editore, Roma

Bartoli L, De Rosa M, Sabbatini M (2011) Pressione socio-economica e strategie emergenti delle aziende agricole. Franco Angeli, Milano

Bass BM (1985) Leadership and performance beyond expectations. Free Press, New York

Becker G (1962) Investments in human capital: a theoretical analysis. J Polit Econ 70(5):9-44

Becker G (1975) Human capital: a theoretical and empirical analysis with special reference to education. Columbia University Press, London

Benedetto G (2011) Capitale sociale, capitale umano e sviluppo dei sistemi rurali. In: Idda L, Pulina P (eds) Impresa agricola familiare, capitale umano e mercato del lavoro. Franco Angeli, Milano, pp 269-309

Bradburn NM, Wansink B, Sudman S (2004) Asking questions: the definitive guide to questionnaire design—for market research, political polls, and social and health questionnaires. Wiley, San Francisco, CA

Burns JM (1978) Leadership. Hapeer \& Row, New York

Ciuffoletti Z, Contini G (1994) Studi sull'agricoltura italiana: società rurale e modernizzazionne. Fondazione Giangiacomo Feltrinelli, Milano

Corinto GL (2014) La TV degli agricoltori. The Italian television broadcasting for farmers until 1970. Agricoltura Istituzioni Mercati 3:41-156

Couniham CM (2004) Around the Tuscan Table. Food, family, and gender in twentieth century in Florence. Routledge, London

De D'Attorre PP, Bernardi A (1994) Studi sull'agricoltura italiana: società rurale e modernizzazione. Fond. Giangiacomo Feltrinelli, Milano

Europea C (2002) L'agricoltura al femminile. Comunità Europee, Belgio

Goleman D (2001) Emotional intelligence: issues in paradigm building. In: Cherniss C, Goleman D (ed) The emotionally intelligent workplace. Chapter 2. http://www.eiconsortium.org/pdf/ emotional_intelligence_paradigm_building.pdf. Accessed 5 Jan 2015

ISTAT (2002) $5^{\circ}$ Censimento dell'agricoltura. ISTAT, Roma

ISTAT (2010) $6^{\circ}$ Censimento dell'agricoltura. ISTAT, Roma

Jones P (1980) Le origini medievali della moderna società rurale. Un caso tipico: il passaggio dalla curtis alla mezzadria. In: Jones $\mathrm{P}$ (ed) Economia e società nell'Italia medievale. Einaudi, Torino, pp 377-433

Kvale S (1996) Interviews: an introduction to qualitative research interviewing. Sage, London 
Marshall MN (1996) The key informant technique. Fam Pract 13:92-97

Mediobanca (2014) Indagine sul settore vinicolo. Ufficio Studi di Mediobanca, Milano

Mennell S, Murcott A, van Otterloo AH (1992) The sociology of food: eating, diet and culture. Sage, London

Nye JS (2004) The means to success in world politics. Public Affairs, New York

Piacentini M (2013) OECD social, employment and migration working papers. OECD, p 147

Piccardo C, Baiunco M (2007) Leader donne: essere donne e leader fa la differenza? Sviluppo Organizzazione 221:1-14

Piccardo C, Baiunco M, Emanuel F (2008) La leadership al femminile. In: Argentero P, Cortese CG, Piccardo C (eds) Psicologia del lavoro. Raffaello Cortina, Milano

Polidori R (2013) Paesaggio e integrazione: le eredità della mezzadria per la Pac del futuro. Agriregionieuropa 32:74

Rea A (2009) Scenari di Marketing del vino. Una prospettiva al femminile. Osservatorio Vino. Franco Angeli, Milano

Rosenberg NJ (1963) Technological change in the machine tool industry, 1840-1910. J Econ Hist 23(4):414-443

Sabbatini M (2006) Donne della terra: i loro "numeri" per e nell'agricoltura. ISTAT, Roma

Schultz TW (1960) Capital formation in education. J Polit Econ 68(4):571-583

Schultz TW (1964) Transforming traditional agriculture. Yale University Press, New Haven

Tazza A (2010) Spiritualità e operosità delle donne imprenditrici. Risultati di un'inchiesta e testimonianze. Franco Angeli, Milano

Tremblay MA (1955) The key informant technique: a non-ethnographic application. Am Anthropol 59(4):688-701

Unioncamere (2011) Imprese in genere. $2^{\circ}$ rapporto nazionale sull'imprenditoria femminile. Ministero dello Sviluppo Economico. Dipartimento per le Pari Opportunità e Unioncamere, Roma 